\title{
The impact of social support on work-to-family and family-to-work conflict: An analysis on the female primary school teachers of Bangladesh
}

Tabassum, Ayesha

Faculty of Business Administration, Eastern University, Bangladesh (tabassum105@yahoo.com)

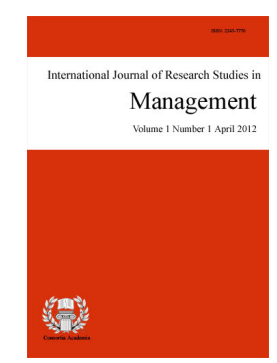

ISSN: $2243-7770$ Online ISSN: 2243-7789

Received: 2 June 2012

Revised: 20 June 2012

Accepted: 22 June 2012

OPEN ACCESS

\section{Abstract}

Employed women usually face work-family conflict, as they need to maintain both the work and family responsibilities. In Bangladesh, a large number of educated women are employed as female teachers in the primary education sector. Like any other sector, these primary school teachers are also expected to have a significant amount of work-family conflict. Literature review suggests that social support, i.e. support from supervisor, co-worker, spouse, and family members can significantly reduce two types of work-family conflict; (a) work-to-family conflict and (b) family-to-work conflict. Based on this background the current study initiated to investigate how social support from supervisor, co-workers, life partner, and family members is associated with work-family conflicts in $\mathrm{N}=90$ female primary school teachers. A structured questionnaire was used as a mean primary source of data collection. Results revealed that spouse support and family support was negatively related with family-work conflict, though no negative relation were found between supervisor support and work-family conflict, and co-worker support and work-family conflict.

Keywords: work-family conflict; family-work conflict; sources of social support; school teachers; employed women 


\section{The impact of social support on work-to-family and family-to-work conflict: An analysis on the female primary school teachers of Bangladesh}

\section{Introduction}

Education is one of the major indicators of socio-economic development of a country. Thus the government of Bangladesh has emphasized greatly on primary education as education at primary level is the prime ingredient of human resource development in the country (Democracywatch, 2002). In Bangladesh, the access of primary education is maintained mainly by the government. More than $75 \%$ schools are controlled by the government and around $83 \%$ of the total children enrolled in these government controlled primary schools. Similarly, more than $70 \%$ primary teachers are working in the government controlled schools (Baseline Survey, 2005). The participation of female teachers in the primary schools has increased to $60 \%$, improved from $33.9 \%$ in the year 2000 (CPD, 2001). Despite this increase in women's employment, however, the traditional gender-role expectations concerning men and women's roles in the society appear to be little eroded (Noor, 2003). Traditionally the work role is seen to be men's primary domain and women are still primarily responsible for the home and children (Doucet, 2000; Windebank, 2001). That's why employed women have to juggle the demands from both work and family roles to a greater degree than employed men (Noor, 2003), which eventually creates an imbalance between these two types of roles, which is known as work-family conflict (WFC).

WFC is "a form of inter-role conflict in which the role pressures from the work and family domains are mutually non-compatible in some respect. That is, participation in the work (family) role is made more difficult by virtue of participation in the family role (Greenhaus \& Beutell, 1985, p. 76)". Frone, Russell and Cooper (1992) have identified two types of WFC; one is work-to-family conflict (WFC), which happens when work is interfering family and the other is family-to-work conflict (FWC), happens when family is interfering work. Noor (2003) explained these two types of conflicts with examples. According to this researcher, WFC occurs when work-related activities spill over or interfere with home responsibilities (e.g. bringing work home and trying to complete them at the expense of family time) and FWC arises when family-role responsibilities spill over or impede work activities (e.g. having to cancel an important meeting because a child is suddenly taken ill). Past researchers found that high levels of both WFC and FWC are associated with decreased levels of job satisfaction and lower levels of psychological well-being (e.g. Frone, Russell, \& Cooper, 1992; Kinnunen \& Mauno, 1998; Thomas \& Ganster, 1995; Duxbury \& Higgins, 1991; Thompson \& Blau, 1993), and life satisfaction (Judge, Boudreau, \& Bretz, 1994).

In general it is more likely that women will experience greater amount of conflict from family domain and men will experience more conflict from work domain (Bailyn, Rapport, Kolb, \& Fletcher, 1996). But women report to experience more WFC than men as they spend more combined time on work and family activities (Frone, Russell, \& Cooper, 1992; Hammer, Allen, \& Grigsby, 1997; Lundberg, Mardberg, \& Frankenhaeuser, 1994). In fact employed women spend many more hours than employed men on family and household chores and more hours on work and family activities in total (Hochschild, 1989). Higgins, Duxbury and Lee (1994) provided with specific example about this fact that "employed husbands spend about half the time employed wives spend on household and two thirds the time they spend in child care". This mainly happens due to the traditional sociocultural gender role-expectations theory, according to which, women assume primary responsibility for the family (see Schwartz, 1992; Hochschild, 1989). It is also evident from the research literature that women's work and family-role demands are higher than men's. Men have more control over the distribution of their time, which, in turn, should make it easier for them to satisfy both work and family expectations (Higgins, Duxbury, \& Lee, 1994). According to previous researches, WFC has been shown to be associated with social support from different sources such as supervisors, co-workers, spouses, and family (e.g., Carlson \& Perrewé, 1999; Cohen \& Wills, 1985). This study analyzed the interplay between the four different 
The impact of social support on work-to-family and family-to-work conflict in Bangladesh

sources of social support (supervisors, co workers, partners, and other family members) and different forms of conflict among work and family, i.e. WFC and FWC.

But most previous researches that investigated work-family conflict among women focused on demanding managerial and non-traditional professions. According to Cinamon and Rich (2005), researchers did not perceive teachers as a prolific target for study, probably from the assumption that teachers experience low levels of work-family conflict. These researchers identified two reasons behind such assumptions; "the ranks of teachers include a preponderance of women who attribute high importance to family but not to work roles; and that teaching has characteristics that enable compatible relations between work and family roles (Cinamon \& Rich, 2005, p. 366)". However, Cinamon and Rich (2005) along with other researchers (see Carter \& Doyle, 1996; Van der Berg, 2002) have raised questions about the accuracy of these assumptions. Therefore the current study addressed the issue of WFC among the women teachers in context of Bangladesh. Figure 1 provides a graphic depiction of the proposed theoretical model integrating the relationships among the variables. Data were collected from the Government owned or public primary school teachers and tests were conducted for measuring the theoretical model.

\section{Theoretical Overview of WFC and FWC}

Most of the early researches measured WFC, but did not identify the direction of conflict. That means the researchers did not explore whether the work roles are interfering in the family or the family roles are interfering in the work (Mesmer-Magnus \& Viswesvaran, 2005). Thus the work domain that obstruct performance in the family domain (work-to-family conflict; WFC) and family demands that hinder performance in the work domain (family-to-work conflict; FWC) are conceptually distinct (Netemeyer, Boles, \& McMurrian, 1996). Kossek and Ozeki (1998) have suggested that FWC is more impacted by variables within the family domain, while WFC is more influenced by work-related variables. So for better understanding the nature of WFC, it is important to consider the bi-directional conceptualization of WFC (Frone, Russell, \& Cooper, 1992). Many of the researchers questioned about the fact that whether WFC and FWC are correlated with each other. As conflicts in one direction are likely to be coupled with expressions of conflict in the other direction, an overlap is expected between WFC and FWC (Frone, Russell, \& Cooper, 1992).Though positive correlations were found between these two types of conflicts (Gutek, Searle, \& Klepa, 1991; Flye, Agars, \& Kottke 2003), researchers have proceeded that WFC and FWC are distinct. Mesmer-Magnus and Viswesvaran (2005) clarified the differential pattern of WFC and FWC in their researches through vast literature review, where they mentioned, "WFC will correlate higher with job stressors and job satisfaction than FWC, but FWC will correlate higher (than WFC) with life satisfaction and non-job stressors (p. 217)". Thus such an assumption needs to be empirically verified and for this purpose the current study tested the following hypotheses.

Hypothesis 1: A high inter-correlation subsists between WFC and FWC

After reviewing literatures the current researcher is convinced about the fact that the following categories of external variables are generally examined in the studies of WFC and FWC: (a) job-related stressors, (b) level of support received from work environment, (c) level of support received from family (i.e. spouse and other family members), (d) job/career satisfaction, (e) family (marital) satisfaction, (f) life satisfaction, (g) physical and mental health, and (h) other work or non-work related influences. The current study considers social support that is support from work and support from family as having influential impact on WFC and FWC.

\subsection{Work and Family of Teachers}

Etzioni (1969) characterized teaching and other female-dominated occupations as "semi-professions". This implied that teachers display little unique professional knowledge and that's why they are not very committed to their work (Spencer, 1997). Thus, teaching was considered an especially appropriate occupation for women because they would be able to combine work and family roles with a minimum of conflict with little investment 
in work (Cinamon \& Rich, 2005). The same researchers told about another assumption about teaching profession, which stated that job conditions enable teachers to meet their work obligations without major interruptions in family. These researchers identified several studies on female teachers, which reported teachers with young children face difficulty in terms of managing both career and family. They also found that many teachers are incapable of separating their professional and family roles effectively. Thus they came to the conclusion that it is important to study the teachers' work-family relations.

\subsection{Defining Social Support}

Social support is identified as a key component in most of the work-family literatures (Parasuraman, Greenhaus \& Granrose, 1992; Thomas \& Ganster, 1995). Hobfoll and Stokes (1988, p. 499) define social support as "social interactions or relationships that provide individuals with actual assistance or with a feeling of attachment to a person or group that is perceived as caring or loving". The aim of social support is to help a person through the exchange of resources (van Daalen, Willemsen \& Sanders, 2006). This can take place in form of instrumental, emotional and informational support. Emotional support typically involves providing empathy, care, love and trust (House, 1981). Instrumental support includes actual aid in time, money and energy, whereas appraisal support may involve providing information relevant to self-evaluation, and informational support includes advice, information and suggestions (House, 1981, p. 39). Researchers have identified two sources of social support; support from work and support from family. Work social support refers to instrumental aid, emotional concern, informational, and appraisal functions of others in the work, whereas family social support refers to instrumental aid, emotional concern, informational, and appraisal functions of others in the family domain that are intended to enhance the well-being of the recipient (House, 1981; Matsui, Ohsawa, \& Onglatco, 1995; Shumaker \& Brownell, 1984). Thus these researchers proposed that social support might reduce work-family conflict in two ways; (1) social support could "reduce certain role pressures", or (2) "moderate the relationship between work-family conflict and psychological well-being". The current study analyzes the interplay between the four different sources of social support (supervisors, co-workers, partners, and other family members) and two directions of work-family conflict (WFC and FWC).

\subsection{Work Social Support and WFC}

Social support in the work domain may come from a number of sources, such as coworkers or supervisors, who creates a positive working environment (Carlson \& Perrewé, 1999). A supportive supervisor may make work situations less stressful by discussing family-related problems and being flexible when emergencies arise, which in turn reduces the work-related stress and influences the WFC to decrease. Lower work-family conflict was found for the employees who had supportive supervisors (Goff, Mount, \& Jamison, 1990; Jones \& Butler, 1980; Greenhaus \& Beutell, 1985; Greenhaus \& Parasuraman, 1986; Bellavia \& Frone, 2005). On the other hand, lack of social support from work is related to higher levels of work-family conflict (Burke, 1988; Greenhaus \& Powell, 2003). Frone and colleagues' (1997) explained this phenomenon in terms of mediating effects, which exposed that support by supervisor and co-workers can reduce work distress and work overload, thus it eases one's WFC. Several researchers found that support from work is negatively correlated with work-family conflicts (e.g., Carlson \& Perrewé, 1999; Cohen \& Wills, 1985; Ford, Heinen, \& Langkamer, 2007), which indicates that increases amount of work related social support can reduce the WFC among individuals. According to Cohen and Wills (1985), job strains associated with WFC can become less threatening if co-workers and supervisors are perceived as supportive. Thus, the social support in the work domain is an important consideration in the overall evaluation of the work-family conflict phenomenon (Carlson \& Perrewé, 1999). Based on this theoretical framework and existing literature, the following hypotheses are tested.

Hypothesis 2: Social support provided by a supervisor can reduce WFC

Hypothesis 3: Social support provided by coworkers can reduce WFC 


\subsection{Family Social Support and FWC}

Support from the family has been found to play an important role in reducing work-nonwork conflict (Holohan \& Gilbert, 1979). Several past researchers indicated that spousal support can moderate the FWC (e.g. Loerch, Russell, \& Rush, 1989; Matsui, Ohsawa, \& Onglatco, 1995). According to Roskies and Lazarus (1980), a good and open relationship with one's spouse can result in less marital stress. Past studies have found that a husband's support of his wife's employment is critical to the reduction of a working woman's conflict (Berkowitz \& Perkins, 1984; Beutell \& Greenhaus, 1982). On the other hand, low support from spouses regarding their mates' work has been found to be associated with high levels of work-family conflict in dual career couples (Holohan \& Gilbert, 1979).

According to Greenhaus and Powell's (2003, p. 294) explanation, this happens because, "having a work-supportive spouse may increase the likelihood that an individual will choose an important work activity over an equally important family activity, because the individual will feel that the spouse has implicitly granted permission to do so though the offering of support". Moreover, Aryee, Luk, Leung and Lo (1999) and Matsui, Ohsawaa and Onglatco (1995) found in their researches that support from the husband can ease the effect of parental overload on WFC. Besides spousal support, Carlson and Perrewé (1999) included other social network members, such as other family members, friends, who can have a significant impact on reducing FWC. Based on this literature review, the current study tested the following hypotheses.

Hypothesis 4: Social support provided by spouse can reduce FWC

Hypothesis 5: Social support provided by other family members can reduce FWC

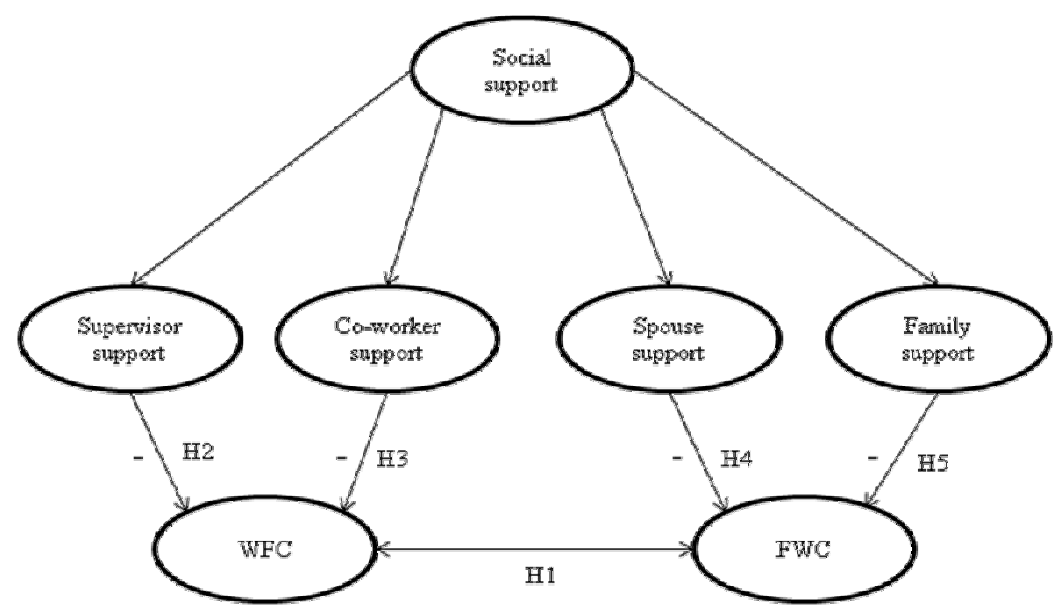

Figure 1. Proposed theoretical model

\section{Methodology}

\subsection{Procedure}

The data were collected in Dhaka, the capital city of Bangladesh by mean of structured questionnaire. Participants were included in the study on a voluntary basis by following several steps of sample inclusion. At first, the sampling criterion was the Thanas of Dhaka city. Generally Thana means police station in the South Asian countries. These Thanas are also known as Upazila in Bangladesh. Upazilas are similar to the county subdivisions found in some Western countries. The Dhaka city is divided into 21 Thanas, from which 10 Thanas were selected based on systematic random sampling technique. For accomplishing this, the Thanas were arranged in alphabetic order. Then 2 Government owned primary schools were selected from each Thana based on convenience. Thus in total 20 Government primary schools were considered for the study. 5 questionnaires 
were distributed in each selected school, which comprised a total of 100 questionnaire distribution. Among these 90 were found to be usable in the research.

\subsection{Participants}

Among the 90 respondents, $2.2 \%$ respondents are below graduate, $42.2 \%$ are graduates, and $55.6 \%$ are post-graduates in terms of education. In the whole sample, $28.9 \%$ of the respondents fall in the age range of 21-30 years, $40 \%$ fall in the 31-40 range, $27.7 \%$ fall in the $41-50$ range, and rest $3.3 \%$ have age range of above 50 years. Among these 90 school teachers, 8 have less than 1 year, 23 have 1 to 5 years, 33 have 6 to 10 years, 22 have 11 to 15 years, and rest 4 have more than 15 years of teaching experience. In terms of working hours, 76 teachers work from 25 to 30 hours, and 14 teachers work from 31 to 40 hours in a week. All the teachers are married and 85 of them have children, among these 23 have one child, 47 have two children, and rests 15 have three children.

\subsection{Measures}

WFC and FWC were measured with the WFC and FWC scale adapted by Ali (2006). The scale includes ten items, such as, "The demands of my work interfere with my home family life" and "The demands of my family or spouse/partner interfere with work related activities" ( $1=$ Never and $5=$ Always $)$. Among these, WFC was measured with five items and FWC was measured with the rest five items. Social support was assessed by using a self-constructed ten-item scale. Respondents were asked to indicate to what extent their partner "gave support in household responsibilities", "gave emotional support", "gave support in childcare responsibilities", and, to what extent their supervisors/colleagues "gave support in balancing work and family", and so on. This scale includes three sub-scales, one for measuring the spouse support, second one is for measuring the support from other family members, and the last one is for measuring work support. The items of the scale were developed based on local context of Bangladesh, where usually a married couple gets support from not only their spouse but also from their parents, in-laws, siblings, full-time/part-time maids for the household and childcare responsibilities. The answer format was a 5-point scale ranging from not at all (1) to a great deal (5).

\subsection{Reliability and Validity of Data}

Validity is the degree which measures accurately represents what it is supposed to (Hair, Black, Babin, Anderson, \& Tatham, 2007). Validity is concerned with how well the concept is defined by the measure(s). There are three types of validity; content validity, predictive validity, and construct validity (Siddiqi, 2010). Duggirala, Rajendran, and Anantharaman (2008) defined the content validity as the assessment of the correspondence between the individual items and concept. Malhotra (2010) defines the content validity as face validity. This study concentrates on content validity through the review of literature and adapts instruments which are used in previous research. Reliability differs from validity in that it relates not to what should be measured, but instead to how it is measured. Reliability is the extent to which a variable or set of variables is consistent in what it is intended to measure (Hair et al., 2007). The current study applies internal consistency method because multiple items in all constructs are used here. The Cronbach alpha with acceptable cut off point 0.70 demonstrates that all attributes are internally consistent (Fujun, Hutchinson, Li, \& Bai, 2007). The Cronbach alpha value for this study is 0.845 that meets the criteria of cut off point. Thus all the attributes of the study are reliable.

\subsection{Data Analysis}

The responses of were analyzed with SPSS. The study is based on the data collected to explore the relationship between social support and WFC or FWC. For this purpose 5-point 'Likert scale' is used that is a numerical and more specifically, interval-scaled data. The corresponding probability distribution of this numerical data point will be a continuous distribution but as the data is informing about the opinion through ranking, it is very likely that the parent distribution will not follow a normal pattern. This pre-assumption has 
The impact of social support on work-to-family and family-to-work conflict in Bangladesh

been further confirmed by illustration of the Probability-Probability plot (P-P plot) of items. The central view and the diversity among the views of the respondents were observed in case of each item individually. The distribution pattern of all the components as a whole expressing all the basic features was observed along with Box-plot diagram. Then, the test of hypothesis was performed with Pearson correlation analysis.

\section{Results}

The Pearson correlation analysis was conducted for hypotheses testing. As according to Welkowitz, Cohen and Ewen (2006), a correlation coefficient is a very useful way to summarize the relationship between two variables with a single number that falls between -1 and +1 . Morgan, Leech, Gloeckner and Barrett (2004) stated that, -1.0 indicates a perfect negative correlation, 0.0 indicates no correlation, and +1.0 indicates a perfect positive correlation.

Table 1

Correlation between WFC and FWC

\begin{tabular}{llcc}
\hline \multicolumn{1}{c}{ Variables } & & WFC & FWC \\
\hline WFC & Pearson Correlation & 1 & \\
& Sig. (2-tailed) & - & 1 \\
FWC & Pearson Correlation & -0.330 & - \\
\hline
\end{tabular}

Note. *Correlation is significant at 0.01 level.

According to the Pearson correlation test result, a significant inter-correlation was found between WFC and FWC $(p<0.01)$ (see Table 1). The r-value indicated a moderate negative relationship between these two forms of conflict, which suggested an increase in one form of conflict can lead a decrease in the other form of conflict.

Table 2

Correlation between work social support and WFC

\begin{tabular}{|c|c|c|c|c|}
\hline Variables & & WFC & Supervisor support & Co-worker support \\
\hline \multirow[t]{2}{*}{ WFC } & Pearson Correlation & 1 & & \\
\hline & Sig. (2-tailed) & - & & \\
\hline \multirow[t]{2}{*}{ Supervisor support } & Pearson Correlation & 0.101 & 1 & \\
\hline & Sig. (2-tailed) & 0.345 & - & \\
\hline \multirow[t]{2}{*}{ Co-worker support } & Pearson Correlation & 0.101 & 0.272 & 1 \\
\hline & Sig. (2-tailed) & 0.343 & 0.009 & - \\
\hline
\end{tabular}

Results from the Pearson correlation tests suggested that there was no significant negative relationship between supervisory support and WFC ( $\mathrm{r}=0.101, p>0.01)$. Thus it was not confirmed whether WFC can be minimized through supervisory support (Hypotheses 2). Similarly no significant association was found between co-worker support and WFC. Moreover the $r$-value was positive $(r=0.101, p>0.01)$ (see Table 2 ). Thus it could not be ascertained that co-worker support can lessen WFC (Hypotheses 3).

Table 3

Correlation between family social support and FWC

\begin{tabular}{llccc}
\hline \multicolumn{1}{c}{ Variables } & & FWC & Spouse support & Family support \\
\hline FWC & Pearson Correlation & 1 & & \\
Spouse support & Sig. (2-tailed) & - & & \\
& Pearson Correlation & -0.278 & 1 & 1 \\
Family support & Sig. (2-tailed) & $* 0.008$ & - & - \\
& Pearson Correlation & -0.176 & 0.105 & - \\
\hline
\end{tabular}

Note. $*$ Correlation is significant at 0.01 level. $* *$ Correlation is significant at 0.1 level.

The Pearson correlation test confirmed a significant negative relationship between spouse support and FWC 
$(\mathrm{r}=-0.278, p<0.01)$ (see Table 3). This result supported Hypotheses 4 and concluded that spouse support can decrease the level of FWC. It was also confirmed that support from other family members can reduce FWC at a significant amount. Thus Hypotheses 5 was supported as the result indicated a significant negative relationship between family support and FWC $(\mathrm{r}=-0.176, p<0.1)$.

\section{Discussion}

The current study investigated the interrelation between WFC and FWC, two forms of work-family conflict. The result did not confirm any positive interrelation between WFC and FWC, though several scholars (Gutek, Searle, \& Klepa, 1991; Flye, Agars, \& Kottke 2003) previously posited the fact that both WFC and FWC increase or decrease simultaneously. WFC, which indicates work-to-family conflict means work's characteristics will interfere in the family domain of a person and FWC, where family characteristics will have a negative impact on work domain, are two separate phenomenons, which is already recognized by the researchers, i.e. Mesmer-Magnus and Viswesvaran (2005). Though WFC is a bi-directional concept, it is not necessary that the person facing WFC will also suffer from FWC. It may happen that individual suffering in WFC due to fact that work have created difficulties to maintain the family responsibilities. But the family roles are not interfering in the work, as the family is comparatively supportive rather than working environment. Thus individual having constraints from work will not always have constraints from his or her family to balance work and family tasks. This type of situation may have an effect on either of an individual's job satisfaction or marital/family satisfaction. Both types of satisfactions may be affected, only if the person suffers from WFC and also FWC.

The present study developed and tested a research model that investigated the effects of social support on WFC. Social support was defined based on different sources. Here two prominent sources were considered; these are family social support and work social support. The hypothesis suggesting that WFC of the female school teachers reduces due to support from their supervisor was not supported by the results. Though previous researches (Carlson \& Perrewé, 1999; Bellavia \& Frone, 2005) found a negative relationship between the supervisor support and WFC, the result of current study showed a positive relationship between these two variables. Similarly, the hypothesis proposing that co-worker support lessens the WFC of the female school teachers was not confirmed by the current study results. Thus these results were not consistent with the previous researches, which confirmed a negative relationship between WFC and co-worker support (Carlson \& Perrewé, 1999; Ford, Heinen, \& Langkamer, 2007).

In this study, FWC was found to be significantly and negatively related with spouse support and family support. Similar findings are obtained by Matsui, Ohsawaa, and Onglatco (1995) and Carlson and Perrewé (1999). The findings indicate that support from spouse and other family members can condense the WFC of the female school teachers, as they more opportunity to balance both the work and family responsibilities. This is very much obvious that supportive spouse and family members would be the strongest sources for working women as they continuously juggle to manage their work and family together.

\subsection{Practical Implications}

The study assesses various relationship patterns among WFC, FWC, and social support. Different sources of social support leading to WFC and FWC in terms of school teachers can be explored from the study. At the same time, the school management can have more elaborated idea regarding the nature of WFC in teaching profession from this study. Therefore, the school management may formulate the work-family polices based on the findings of the current study. As WFC and FWC can significantly reduce job satisfaction and job performance, a collaborative effort of both school management and school teachers is crucial for fostering a family-supportive work environment in the primary schools of Bangladesh. As a result, the school teachers will be able to balance their work and family life, which in turn will motivate them to put more effort in teaching. Thus the current study can be a valuable source of empirical evidences for those practitioners who deal with the teaching employees. 
The impact of social support on work-to-family and family-to-work conflict in Bangladesh

There are limitations to this study that should be noted. First, a significant limitation is the small sample size that was utilized. Moreover, only few schools from Dhaka city have been included in this study. Thus the findings cannot be generalized. Therefore, future research should be conducted on a larger scale by considering more schools from all over Bangladesh to authenticate the relationship between social support and WFC among the female teachers. Second, to determine the sample size and respondents statistically accepted techniques should be utilized. Third, the inferences drawn from this study are limited by self-report data and cross-sectional characteristics of the data.

\section{Conclusion}

Overall the study contributes to work-family literature in several important ways. First, the study replicates previous findings concerning social support and WFC, examining different sources of social support. Second, the study examines the impact of different types of social support on WFC and FWC. Third, the study examines the nature of interrelation between WFC and FWC, which has been a debatable issue among the researchers. Thus the study not only contributes to the scholarly arena, but also it offers implications for the school management. The primary education sector in Bangladesh is dominated by a large number of educated women. This workforce is playing a significant role for economic growth by contributing their knowledge, skills and efforts besides maintaining their family responsibilities. So it is crucial for the practitioners to create a family-supportive workplace that can offer the balance between work and family roles, thus minimizing the inter-role conflict between work and family. In turn it will make the female teachers more satisfied in terms of both job and family and as a result they will contribute more for the growth and development of education sector.

\section{References:}

Aryee, S., Luk, V., Leung, A., \& Lo, S. (1999). Role stressors, interrole conflict, and well-being: The moderating influence of spousal support and coping behaviors among employed parents in Hong Kong. Journal of Vocational Behavior, 54, 174-178. <http://dx.doi.org/10.1006/jvbe.1998.1667>

Bailyn, L., Rapport, R., \& Fletcher, J. (1996). Re-linking work and family: A catalyst for organizational change. Work and Empowerment Journal, 3892-3896.

Baseline Survey. (2005). Baseline report of second primary education development program (PEDP-II). Directorate of Primary Education, Ministry of Primary and Mass Education, Government of the Peoples Republic of Bangladesh.

Bellavia, G. M., \& Frone, M. R. (2005). Work-family conflict. In J. Barling, E. K. Kelloway, \& M. R. Frone (Eds.), Handbook of work stress (pp. 113-147). Thousand Oaks, CA: Sage. <http://dx.doi.org/10.4135/9781412975995.n6>

Berkowitz, A., \& Perkins, H. W. (1984). Stress among farm women: Work and family as interacting systems. Journal of Marriage and the Family, 46, 161-165. <http://dx.doi.org/10.2307/351874>

Beutell, N. J., \& Greenhaus, J. H. (1982). Interrole conflict among married women: The influence of husband and wife characteristics on conflict and coping behavior. Journal of Vocational Behavior, 21, 99-110. $<$ http://dx.doi.org/10.1016/0001-8791(82)90055-0 >

Burke, R. J. (1988). Some antecedents and consequences of work-family conflict. Journal of Social Behavior and Personality, 3, 287-302.

Carlson, D. S., \& Perrewé, P. L. (1999). The role of social support in the stressor-strain relationship: An examination of work-family conflict. Journal of Management, 25, 513-540. <http://dx.doi.org/10.1177/014920639902500403>

Carter, K., \& Doyle, W. (1996). Personal narrative and life history in learning to teach. In J. Sikula, T. Buttery, \& E. Guyton (Eds.), Handbook of research on teacher education (2nd ed.) (pp. 120-142). New York: Simon \& Schuster.

Cinamon, R., \& Rich, Y. (2005). Work-family conflict among female teachers. Teaching and Teacher Education, 21, 365-378. <http://dx.doi.org/10.1016/j.tate.2004.06.009> 
Tabassum, A.

Cohen, S., \& Wills, T. A. (1985). Stress, social support, and the buffering hypothesis. Psychological Bulletin, 98 , 310-357. <http://dx.doi.org/10.1037/0033-2909.98.2.310>

CPD. (2001). Policy brief on "Education Policy". CPD Task Force Report. Dhaka.

Democracywatch. (2002). A Study on Government Primary Education in Dhaka City. Dhaka: Democracywatch.

Doucet, A. (2000). There's a huge gulf between me as a male career and woman. Gender, domestic responsibility and the community as an institutional arena. Community, Work and Family, 3(2), 163-184. $<$ http://dx.doi.org/10.1080/713658907>

Duggirala, M., Rajendran, C., \& Anantharaman, R. N. (2008). Patient-perceived dimensions of total quality service in healthcare. Benchmarking: An International Journal, 15(5), 560 - 583.

Duxbury, L. E., \& Higgins, C. A. (1991). Gender differences in work-family conflict. Journal of Applied Psychology, 76(1), 60-74. <http://dx.doi.org/10.1037/0021-9010.76.1.60>

Etzioni, A. (1969). The semi-professions and their organizations: Teachers, nurses, social workers. New York: The Free Press.

Flye, L. P., Agars, M. D., \& Kottke, J. L. (2003). Organizational approaches to work-family conflict: Testing an integrative model. Paper presented at the meeting of the Society of Industrial Organizational Psychology, Orlando, FL.

Ford, M. T., Heinen, B. A., \& Langkamer, K. L. (2007). Work and family satisfaction and conflict: A meta-analysis of cross-domain relations. Journal of Applied Psychology, 92, 57-80. <http://dx.doi.org/10.1037/0021-9010.92.1.57>

Frone, M. R., Russell, M., \& Cooper, M. L. (1992). Antecedents and outcomes of work-family conflict: Testing a model of the work-family interface. Journal of Applied Psychology, 77(1), 65-78. $<$ http://dx.doi.org/10.1037/0021-9010.77.1.65>

Frone, M. R., Yardley, J. K., \& Markel, K. S. (1997). Developing and testing an integrative model of the work-family interface. Journal of Vocational Behavior, 50, 145-167. $<$ http://dx.doi.org/10.1006/jvbe.1996.1577>

Fujun, L., Hutchinson, J., Li, D., \& Bai, C. (2007). An empirical assessment and application of SERVQUAL in mainland China's mobile communications industry. The International Journal of Quality \& Reliability Management, 24(3), 244-262.

Greenhaus, J. H., \& Beutell, N. J. (1985). Sources of conflict between work and family roles. Academy of Management Review, 10, 76-88.

Greenhaus, J. H., \& Parasuraman, S. (1986). A work-nonwork interactive perspective of stress and its consequences. Journal of Organizational Behavior Management, 8, 37-60. <http://dx.doi.org/10.1300/J075v08n02_04>

Greenhaus, J. H., \& Powell, G. N. (2003). When and family collide: Deciding between competing role demands. Organizational behavior and human decision processes, 90, 291-303. $<$ http://dx.doi.org/10.1016/S0749-5978(02)00519-8>

Gutek, B. A., Searle, S., \& Klepa, L. (1991). Rational versus gender role explanations for work family conflict. Journal of Applied Psychology, 76(4), 560-568. <http://dx.doi.org/10.1037/0021-9010.76.4.560>

Hair, J. F., Black, W. C., Babin, B. J., Anderson, R. E., \& Tatham, R. L. (2006). Multivariate data analysis. $\left(6^{\text {th }}\right.$ ed.). Upper Saddle River, NJ: Perason Education.

Hammer, L. B., Allen, E., \& Grigsby, T. D. (1997). Work-family conflict in dual-earner couples: Within-individual and crossover cross-over effects of work and family. Journal of Vocational Behavior, 50, 185-203. <http://dx.doi.org/10.1006/jvbe.1996.1557>

Higgins, C., Duxbury, L., \& Lee, C. (1994). Impact of life-cycle stage and gender on the ability to balance family responsibilities. Family Relations, 43(2), 144-150. <http://dx.doi.org/10.2307/585316>

Hobfoll, S. E., \& Stokes, J. P. (1988). The process and mechanics of social support. In S. Duck, D. F. Hay, S. E. Hobfoll, W. Ickes, \& B. M. Montgomery (Eds.), Handbook of personal relationships: Theory, research and interventions (pp. 497-517). Oxford, England: John Wiley \& Sons.

Hochschild, A. (1989). The second shift. New York: Viking.

Holohan, C. K., \& Gilbert, L. A. (1979). Conflict between major life roles: Women and men in dual career 
The impact of social support on work-to-family and family-to-work conflict in Bangladesh couples. Human Relations, 326, 451-467. <http://dx.doi.org/10.1177/001872677903200602>>

House, J. S. (1981). Work stress and social support. Reading, MA: Addison-Wesley.

Jones, A. P., \& Butler, M. C. (1980). A role transition approach to the stresses of organizationally induced family role disruption. Journal of Marriage and the Family, 42, 367-376. <http://dx.doi.org/10.2307/351234>

Judge, T. A., Boudreau, J. W., \& Bretz, R. D. Jr. (1994). Job and life attitudes of male executives. Journal of Applied Psychology, 79(5), 767-782. <http://dx.doi.org/10.1037/0021-9010.79.5.767>

Kinnunen, U., \& Mauno, S. (1998). Antecedents and outcomes of work-family conflict among employed women and men in Finland. Human Relations, 51, 157-177. <http://dx.doi.org/10.1177/001872679805100203>

Kossek, E. E., \& Ozeki, C. (1998). Work-family conflict, policies, and the job-life satisfaction relationship: A review and directions for organizational behavior-human resources research. Journal of Applied Psychology, 83(2), 139-149. <http://dx.doi.org/10.1037/0021-9010.83.2.139>

Loerch, K. J., Russell, J. E. A., \& Rush, M. C. (1989). The relationships among family domain variables and work-family conflict for men and women. Journal of Vocational Behavior, 35, 288-308. <http://dx.doi.org/10.1016/0001-8791(89)90031-6>

Lundberg, U., Mardberg, B., \& Frankenhaeuser, M. (1994). The total workload of male and female white collar workers as related to age, occupational level, and number of children. Scandinavian Journal of Psychology, 35, 315-327. <http://dx.doi.org/10.1111/j.1467-9450.1994.tb00956.x>

Matsui, T., Ohsawa, T., \& Onglotco, M. (1995). Work-family conflict and the stress-buffering effects of husband support and coping behavior among Japanese married working women. Journal of Vocational Behavior, 47, 178-192. <http://dx.doi.org/10.1006/jvbe.1995.1034>

Mesmer-Magnus, J. R., \& Viswesvaran, C. (2005). Convergence between measures of work-to-family and family-to-work conflict: A meta-analytic examination. Journal of Vocational Behavior, 67, 215-232. $<$ http://dx.doi.org/10.1016/j.jvb.2004.05.004>

Morgan, G., Leech, N., Gloeckner, G., \& Barrett, K. (2004). SPSS for introductory statistics, New Jersey: Lawrence Erlbaum Associates, Inc.

Netemeyer, R. G., Boles, J. S., \& McMurrian, R. (1996). Development and validation of work-family conflict and family-work conflict scales. Journal of Applied Psychology, 81(4), 400-410. $<$ http://dx.doi.org/10.1037/0021-9010.81.4.400>

Noor, N. M. (2003). Work- and family-related variables, work-family conflict and women's well-being: some observations. Community, Work \& Family, 6(3), 207-319. <http://dx.doi.org/10.1080/1366880032000143474>

Parasuraman, S., Greenhaus, J. H., \& Granrose, C. S. (1992). Role stressors, social support, and well-being among two-career couples. Journal of Organizational Behavior, 13, 339-356. $<$ http://dx.doi.org/10.1002/job.4030130403>

Roskies, E., \& Lazarus, R.S. (1980). Coping theory and the teaching of coping skills. In P. O. Davidson \& F. M. Davidson (Eds.), Behavioral medicine: Changing health and lifestyle. New York: Brunner/Marzel.

Schwartz, F. (1992). Breaking with traditions: Women and work and the new facts of life. New York: Warner Books.

Shumaker, S. A., \& Brownell, A. (1984). Toward a theory of social support: Closing conceptual gaps. Journal of Social Issues, 40, 11-36. <http://dx.doi.org/10.1111/j.1540-4560.1984.tb01105.x>

Siddiqi, K. O. (2010). Interrelations between service quality attributes, customer satisfaction and customer loyalty in the retail banking sector in Bangladesh. Paper presented in the International Trade \& Academic Research Conference (ITARC) - London 2010.

Spencer, D. A. (1997). Teaching as women's work. In B. Biddle, T. Good, \& I. Goodson (Eds.), International handbook of teachers and teaching (pp. 153-198). Netherlands: Kluwer Academic Publisher.

Thomas, L. T., \& Ganster, D. C. (1995). Impact of family-supportive work variables on work-family conflict and strain: A control perspective. Journal of Applied Psychology, 80, 6-15. <http://dx.doi.org/10.1037/0021-9010.80.1.6>

Thompson, C. A., \& Blau, G. (1993). Moving beyond traditional predictors of job involvement: Exploring the impact of work-family conflict and overload. Journal of Social Behavior and Personality, 8(4), 
Tabassum, A.

635-646.

van Daalen, G., Willemsen, T. M., \& Sanders, K. (2006). Reducing work-family conflict through different sources of social support. Journal of Vocational Behavior, 69, 462-476.

$<$ http://dx.doi.org/10.1016/j.jvb.2006.07.005>

Van der Berg, R. (2002). Teachers' meanings regarding educational practice. Review of Educational Research, 72 , 577-625. <http://dx.doi.org/10.3102/00346543072004577>

Welkowitz, J., Cohen, B.H., \& Ewen, R.B. (2006). Introductory Statistics for the Behavioural Sciences (6th ed.). New Jersey: John Wiley and Sons, Inc.

Windebank, J. (2001). Dual-earner couples in Britain and France: gender divisions of domestic labour and parenting work in different welfare states. Work Employment and Society, 15(2), 269-290.

$<$ http://dx.doi.org/10.1177/09500170122118959> 